\title{
Perancangan Sistem Monitoring dan Controlling Pompa Air secara Wireless Berbasis Android
}

\author{
Regan Tanuatmadja ${ }^{1}$, F.X. Sigit Wijono ${ }^{1}$
}

\begin{abstract}
Water pumping system at home and other places is a very important thing. The purpose of a water pumping system is to save clean water to be used for other convenient things such as drinking and washing. Houses the place that needs the most of water pumping system. Water pumping systems are widely used today in the form of water baloons radar at a certain height point at water torrent. Along with the development of technology, water pumping systems become more controllable and practical. The design of this water pumping system uses Bluetooth and water height detection sensor. The water pumping system allows the house owners to know the height of the water in the water torrent immediately and remotely. Water detection inside the water torrent is done by installing the water detection sensor that use the infrared sensor at the water torrent. When the sensors detect a blockade or a value change at the designated level, then system will automatically send the display similar to handphone battery charges. The overall design of this system uses the CodeVision AVR and web-based AppInventor. The effective range between Bluetooth module and the Android smartphone is approximately 8 metres, because when the range is above 8 metres, the transmitting signal to relay will reduce the precision and became more unstable depending on the room situation between smartphone and the Bluetooth module. The design of this system is done by using a power supply module, water height detection module, the relay module, Bluetooth module, microcontroller module, smartphone, micro program module, and Android program module. The whole water pumping system is controlled by an Android smartphone which serves as the main system controller. Based on the test results, the entire water pumping system works properly. Each module works according to the design and perform a good water pumping system.
\end{abstract}

KEYWORD: Water pump, water height, detector.

\begin{abstract}
ABSTRAK : Sistem perairan pompa dalam suatu gedung atau rumah merupakan suatu hal yang sangat penting. Tujuan sistem perairan pompa adalah untuk menampung air bersih untuk digunakan untuk berbagai kebutuhan mulai dari minum hingga mencuci. Tempat yang paling membutuhkan air adalah rumah. Sistem pompa yang banyak digunakan saat ini yaitu berupa radar pelampung yang dipasangkan pada bagian paling atas torren air yang diisi. Sesuai dengan perkembangan teknologi, sistem pompa air menjadi lebih terkontrol dan praktis. Perancangan sistem pompa air ini menggunakan koneksi Bluetooth serta sensor pendeteksi ketinggian air. Sistem pompa air ini memungkinkan pemilik rumah secara langsung dan dalam jarak jauh dapat mengetahui pengisian torren air yang dilakukan pompa. Pendeteksian air yang diisi kedalam torren dilakukan dengan memasangkan sensor pendeteksi air yang menggunakan sensor inframerah pada torren air. Pada saat sensor mendeteksi halangan atau perubahan nilai deteksi pada level yang ditentukan, maka secara otomatis akan ditampilkan pada smartphone Android pemilik rumah dan memiliki tampilan seperti mengisi ulang batere handphone. Perancangan dari keseluruhan sistem ini menggunakan software CodeVision AVR dan web-based AppInventor. Jarak efektif antara modul Bluetooth dan smartphone Android adalah kurang lebih 8 meter, karena saat jarak ada diatas 8 meter, waktu penerimaan sinyal ke relay menjadi kurang presisi dan mulai tidak stabil tergantung dengan kondisi ruang antara smartphone dengan Bluetooth. Perancangan sistem ini dilakukan dengan menggunakan modul catu daya, modul pendeteksi ketinggian air, modul relay, modul bluetooth, modul mikrokontroler, smartphone, modul program mikro, dan modul program android. Keseluruhan sistem ini dikendalikan dengan smartphone Android yang berfungsi sebagai pengontrol utama. Berdasarkan dari hasil pengujian yang dilakukan, sistem pompa berjalan dengan baik secara keseluruhan. Setiap modul bekerja sesuai dengan awal rancangan dan menjadi sebuah sistem yang bekerja dengan baik.
\end{abstract}

KATA KUNCI: Pompa air, ketinggian air, pendeteksi.

\section{PENDAHULUAN}

A ir merupakan sebuah unsur kehidupan manusia yang sangat vital. Manusia membutuhkan air untuk berbagai kebutuhan mulai dari kehidupan sehari - hari hingga pembangkit listrik. Air yang digunakan untuk kehidupan sehari - hari tentu saja merupakan air bersih yang sudah disaring dan didistribusikan oleh Perusahaan Daerah Air Minum ( PDAM ) yang terdapat di setiap provinsi, kabupaten, dan kotamadya di seluruh Indonesia. Distribusi air bersih dari PDAM ke masyarakat umum disimpan ke suatu wadah penyimpanan yang ada di setiap gedung di seluruh penjuru kota yang dikenal dengan sebutan toren air. Pengisian toren tersebut dibantu oleh pompa air yang dapat diatur melalui alat kontrol level ketinggian air yang sudah banyak saat ini dikenal dengan pelampung pendeteksi. Alat ini lebih dikenal masyarakat sebagai pelampung pengukur ketinggian level air pada pompa air. Radar berfungsi untuk men-trigger switch off saat permukaan air mencapai batas maksimal atau membuat pelampung naik dan mencapai batas maksimal. Namun, pelampung pendeteksi ini memiliki kelemahan dalam sistem pendeteksinya, saat permukaan air sudah mulai mencapai pelampung, maka radar ini akan mendeteksinya sebagai hasil bahwa air sudah mencapai batas level maksimal dan akan mulai meng-switch kondisi pompa menjadi off, kemudian berubah kembali menjadi kondisi on lagi dikarenakan permukaan air masih belum stabil dan terus - menerus men-trigger kondisi on dan off terus menerus sampai level permukaan air betul - betul mencapai batas maksimal. Sistem yang akan dirancang adalah sistem kontrol level toren dengan sensor fotodioda melalui Bluetooth berbasis Android. Sistem ini diharapkan dapat mengurangi penggunaan daya listrik yang tidak stabil saat level permukaan air mulai mencapai batas yang hampir maksimal.

Perbandingan hasil survei dengan sistem yang akan dirancang didapat berdasarkan hasil survei yang telah dilakukan dari pengamatan cara kerja pompa air dan Radar pelampung pada perumahan yang menggunakan Radar pelampung biasa. Perbandingan hasil survei dengan sistem yang dirancang dapat dilihat pada Tabel 1

${ }^{1}$ Program Studi Teknik Elektro, Fakultas Teknik Universitas Tarumanagara 
- Tabel 1. Perbandingan hasil survei dengan alat yang dirancang

\begin{tabular}{cccc}
\hline No. & Survei pertama & Survei kedua & Sistem yang dirancang \\
\hline 1 & $\begin{array}{c}\text { Kondisi on/off tergantung pada } \\
\text { gerakan pelampung sehingga } \\
\text { tidak stabil. }\end{array}$ & $\begin{array}{c}\text { Kondisi off apabila } \\
\text { pelampung trigger } \text { off } \\
\text { selama 10 detik. }\end{array}$ & $\begin{array}{c}\text { Dapat dimatikan secara } \\
\text { otomatis melalui Android. }\end{array}$ \\
\hline 2 & $\begin{array}{c}\text { Hanya dapat mendeteksi saat air } \\
\text { penuh. }\end{array}$ & $\begin{array}{c}\text { Hanya dapat mendeteksi } \\
\text { saat air penuh. }\end{array}$ & $\begin{array}{c}\text { Dapat dideteksi sesuai dengan } \\
\text { jumlah pendeteksi yang } \\
\text { dipasang pada toren. }\end{array}$ \\
\hline 3 & Hanya dapat mendeteksi ketika \\
air penuh. & $\begin{array}{c}\text { Hanya dapat mendeteksing } \\
\text { ketika air penuh. }\end{array}$ & $\begin{array}{c}\text { Dapat mendeteksi ketinggian } \\
\text { level air ketika torren sedang } \\
\text { diisi. }\end{array}$ \\
\hline
\end{tabular}

\section{KAJIAN PUSTAKA}

Sistem yang akan dirancang ini melakukan deteksi air melalui modul pendeteksi air sesuai dengan jumlah pendeteksi yang sudah dipasang dalam torren air. Hasil deteksi dikirimkan melalui bluetooth dan dikirimkan ke smartphone berbasis Android milk user. Tampilan pengisian air akan ditampilkan ke user pada smartphone berbasis Android. Sistem operasi yang digunakan adalah Android, karena Android merupakan sistem operasi yang berbasis Linux, yang pastinya Android bersifat terbuka oleh karena itu banyak pengembang yang ingin mengembangkan, sehingga dari versi pertama dan hingga terakhir 4.0 dengan cepat dirilis, dan juga Android lebih cepat berkembang karena Android diakusisi oleh Google, yang merupakan raksasa mesin pencari saat ini , jadi tidak sulit untuk mengembangkan aplikasi Android sendiri [1]. User dapat memantau perubahan level ketinggian air dan memasukkan input on/off melalui layar touch screen smartphone. User juga dapat menentukan batasan sehingga torren tidak diisi penuh untuk keperluan lain seperti membersihkan torren. Pendeteksi ketinggian level air yang digunakan adalah fotodioda yang dipasangkan berpasangan dengan LED inframerah. LED atau dioda pemancar cahaya adalah dioda yang dioperasikan pada arah maju dan mengubah energi listrik menjadi emisi cahaya, baik cahaya tampak maupun cahaya tak tampak [2].

Ketinggian air dideteksi dengan meletakkan sebuah objek yang dapat mengapung di permukaan air sehingga menghalangi pancaran cahaya yang dihasilkan LED ke fotodioda, karena semakin kuat cahaya yang dipancarkan, semakin besar arus balik dioda. Sifat ini menjadikan fotodioda cocok untuk digunakan sebagai detektor cahaya [3]. Semakin fokus jenis LED maka kemungkinan gagal mendeteksi dapat dihilangkan. Komunikasi antara mikro dan pompa menggunakan bluetooth. Bluetooth sendiri merupakan sebuah teknologi komunikasi wireless (tanpa kabel) yang beroperasi dalam pita frekuensi 2,4 GHz yang mampu menyediakan layanan komunikasi data dan suara secara real-time antara host-host bluetooth dengan jarak jangkauan layanan yang terbatas (sekitar 10 meter) [4]. Data hasil sensor kemudian dikirimkan ke smartphone untuk ditentukan oleh user langkah selanjutnya. Setelah data hasil sensor dikirimkan dan diterima ke smartphone user, user dapat melihat kenaikan ketinggian level air sesuai dengan jumlah sensor fotodioda dan LED yang sudah dipasangkan dalam torren. User kemudian dapat men-switch on / off pompa dari smartphone dan menentukan batasan untuk menghidupkan dan mematikan pompa sesuai dengan ketinggian level air yang sudah ditentukan.

\section{Diagram Blok}

Pada perancangan ini menggunakan jenis sensor inframerah yang berfungsi untuk mendeteksi adanya perubahan level air. Setiap sensor tersebut terhubung dengan modul Mikrokontroler. Modul Mikrokontroler berfungsi sebagai penghubung antara sensor dengan modul lainnya. Input dari sensor diproses oleh Mikrokontroler untuk ditampilkan di smartphone Android. Setelah menerima input dari sensor maka pada smartphone Android akan ditampilkan posisi air yang sudah dideteksi oleh sensor sehingga muncul gambar air dengan ketinggian yang sudah disiapkan. Diagram blok dari rancangan sistem ini dapat dilihat pada Gambar 1. 


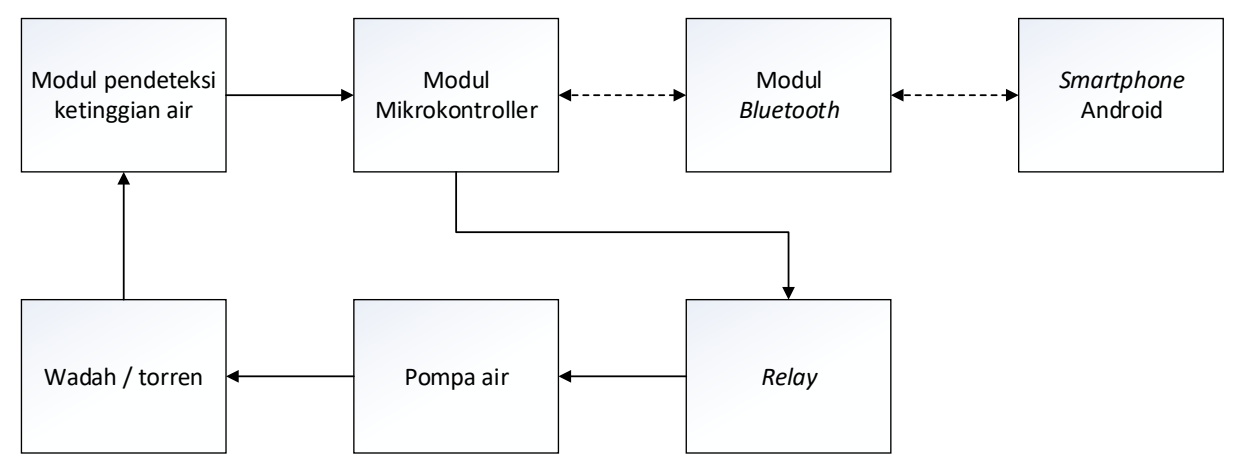

- Gambar 1. Diagram Blok

Pada smartphone Android juga sudah disediakan tombol on / off pompa yang sudah dihubungkan dengan relay. Smartphone memberikan perintah kepada modul Mikrokontroler untuk men-switch on/off relay dan menerima data hasil sensor melalui modul Bluetooth.

\section{Catu Daya}

Perancangan pompa otomatis ini menggunakan sebuah modul catu daya untuk menghasilkan tegangan 5 Volt Direct Current (DC) dan juga $12 \mathrm{~V}_{\mathrm{DC}}$. Modul catu daya atau disebut juga power supply merupakan modul yang berfungsi untuk memberikan supply listrik kepada peralatan elektronik lainnya agar dapat beroperasi. Input dari catu daya berupa tegangan Alternating Current (AC) sebesar $220 \mathrm{~V}_{\mathrm{AC}}$ yang berasal dari Perusahaan Listrik Negara (PLN). Catu daya tersusun atas komponen-komponen elektronik sehingga dapat mengubah tegangan 220 $\mathrm{V}_{\mathrm{AC}}$ menjadi $5 \mathrm{~V}_{\mathrm{DC}}$ dan $12 \mathrm{~V}_{\mathrm{DC}}$. Pada umumnya komponen-komponen tersebut antara lain: transformator, rectifier, filter, dan IC regulator. Pada sistem ini, transformator berfungsi untuk menurunkan tegangan 220V dari PLN sehingga trafo yang digunakan adalah trafo step down. Rectifier terdiri dari dioda yang berfungsi merubah arus bolak balik menjadi arus searah[5]. Setelah itu, dilakukan proses filter oleh kapasitor untuk memperhalus tegangan searah dari rectifier dengan cara membuang tegangan ripple. IC regulator berfungsi untuk menstabilkan tegangan keluaran agar sesuai dengan yang diinginkan.

Pengujian dengan beban dilakukan dengan cara mengukur tegangan keluaran dari catu daya yang telah diberi beban. Beban yang digunakan pada pengujian ini adalah resistor dengan beban $220 \mathrm{Ohm}$ dan $1000 \mathrm{Ohm}$. Tujuan dari pengujian dengan beban ini yaitu untuk mengetahui apakah modul catu daya tetap menghasilkan tegangan keluaran yang stabil ketika diberi beban.

- Tabel 2. Hasil Pengujian Modul Catu Daya 5 Volt

\begin{tabular}{cccc}
$\begin{array}{c}\text { Pengujian } \\
\text { Ke- }\end{array}$ & $\begin{array}{c}\text { Beban Pengujian } \\
(\Omega)\end{array}$ & $\begin{array}{c}\text { Tegangan Tanpa Beban } \\
(\mathrm{V})\end{array}$ & $\begin{array}{c}\text { Tegangan dengan Beban } \\
(\mathrm{V})\end{array}$ \\
\hline 1 & $1000 \Omega$ & 5,02 Volt & 5 Volt \\
2 & $220 \Omega$ & 5,02 Volt & 5 Volt \\
\hline
\end{tabular}

Pengujian kedua yaitu pengujian catu daya $12 \mathrm{~V}_{\mathrm{DC}}$ dengan beban dan tanpa beban. Beban yang digunakan pada pengujian catu daya $12 \mathrm{~V}_{\mathrm{DC}}$ adalah resistor dengan tahanan $1000 \mathrm{Ohm}$ dan $220 \mathrm{Ohm}$.

Tabel 3. Hasil Pengujian Modul Catu Daya 12 Volt

\begin{tabular}{cccc}
\hline $\begin{array}{c}\text { Pengujian } \\
\text { Ke- }\end{array}$ & $\begin{array}{c}\text { Beban Pengujian } \\
(\Omega)\end{array}$ & $\begin{array}{c}\text { Tegangan Tanpa Beban } \\
(\text { V) }\end{array}$ & $\begin{array}{c}\text { Tegangan dengan Beban } \\
(\mathrm{V})\end{array}$ \\
\hline 1 & $1000 \Omega$ & 12,03 Volt & 12,03 Volt \\
2 & $220 \Omega$ & 12,03 Volt & 12,03 Volt \\
\hline
\end{tabular}

Berdasarkan hasil pengujian modul catu daya, dapat disimpulkan bahwa modul catu daya bekerja dengan baik. Hal ini dibuktikan dari hasil pengujian, masing-masing dari output catu daya $5 \mathrm{~V}_{\mathrm{DC}}$ dan $12 \mathrm{~V}_{\mathrm{DC}}$ menghasilkan tegangan keluaran sesuai dengan yang dibutuhkan, tegangan keluaran dari modul catu daya tetap stabil pada saat diberi beban maupun tanpa beban dan dapat dipakai untuk sumber tegangan dari sistem pompa otomatis ini 


\section{Modul Relay}

Modul relay atau dapat disebut juga sebagai modul pengontrol merupakan suatu rangkaian yang digunakan untuk mengendalikan suatu peralatan elektronik. Pada perancangan ini, modul relay terdiri dari serangkaian relay, transistor, resistor dan dioda. Relay merupakan suatu saklar yang dapat diaktifkan secara otomatis apabila lilitan (coil) diberi arus listrik. Keadaan kontak relay dapat dibedakan menjadi dua yaitu Normally Open (NO) dan Normally Close (NC). Pada kondisi Normally Open, kontak relay berada dalam kondisi terbuka dan akan tertutup apabila relay aktif. Pada kondisi Normally Close, kontak relay berada pada keadaan tertutup dan akan terbuka pada saat relay aktif. Selain NO dan NC, pada relay juga terdapat bagian Comm. Bagian Comm dari relay terhubung langsung dengan beban yang digunakan. Kontak NO atau NC terhubung dengan sumber tegangan yang akan digunakan untuk mengaktifkan beban. Pada saat coil (lilitan) mendapatkan arus listrik, maka relay akan aktif dan kemudian terjadi perubahan kontak di dalam relay. Rangkaian Pengujian Modul Relay dapat dilihat pada Tabel dan gambar di bawah ini

- Tabel 4 Hasil Pengujian Modul Relay

\begin{tabular}{|c|c|}
\hline Input & Tegangan Output $\left(\mathbf{V}_{\mathrm{AC}}\right)$ \\
\hline OFF & $0 \mathrm{~V}$ \\
\hline ON & $220 \mathrm{~V}$ \\
\hline
\end{tabular}

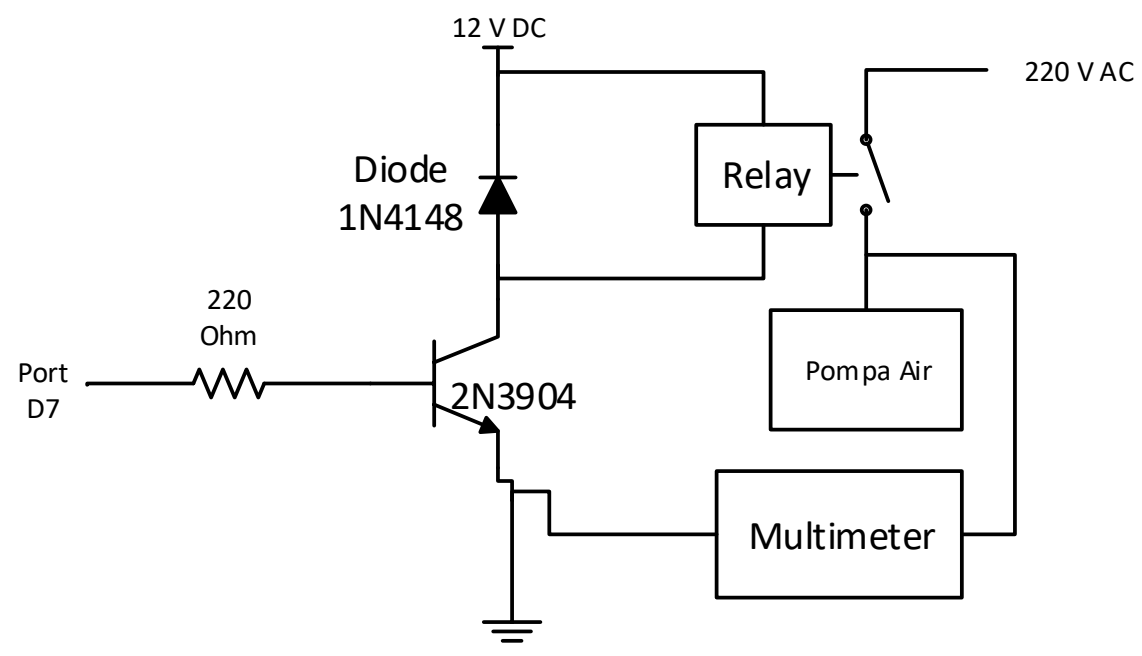

- Gambar 2. Rangkaian Pengujian Modul Relay

\section{Modul Pendeteksi Ketinggian Air}

Modul pendeteksi ketinggian air terbagi menjadi 2, yaitu modul LED indikator dan modul penerima sinyal. Modul indikator pada perancangan ini merupakan suatu modul yang digunakan untuk menandakan ketinggian air dari sistem ini. Modul indikator terdiri dari Light Emitting Diode (LED) dan resistor. LED yang digunakan adalah LED inframerah sebanyak 3 buah dan dirangkai secara terpisah. LED adalah suatu dioda yang dapat menghasilkan cahaya pada saat mendapatkan arus listrik. LED terdiri dari gabungan unsur logam aluminium, gallium dan arsenit. Warna dari LED bermacam-macam antara lain: merah, hijau, biru, putih, dan lainnya. LED inframerah digunakan untuk menghasilkan radiasi inframerah. Prinsip dasar dari sebuah LED adalah merupakan $P-N$ Junction yang memancarkan radiasi inframerah atau cahaya yang tidak kelihatan, apabila $P-N$ Junction ini dihubungkan secara prategangan maju (forward bias). LED inframerah sering diaplikasikan sebagai transmitter cahaya inframerah pada remote control dan pengukur jarak tanpa kabel.

Arus listrik yang digunakan untuk menyalakan lampu LED maksimal sebesar $20 \mathrm{~mA}$. Apabila arus yang digunakan melebihi $20 \mathrm{~mA}$ maka lampu LED akan terbakar dan rusak. Oleh sebab itu, untuk menyalakan LED biasanya diberi resistor terlebih dahulu untuk menghambat arus listrik. LED terdiri dari dua kaki yaitu kaki anoda dan katoda. Kaki anoda dari LED terhubung dengan tegangan positif sedangkan kaki katoda terhubung dengan tegangan negatif. Modul penerima sinyal terdiri dari fotodioda inframerah dan resistor dengan rangkaian dan konsep yang sama dengan LED. Fotodioda akan aktif apabila terkena cahaya dari LED inframerah. Antara LED 
dan fotodioda dipisahkan oleh jarak. Jauh dekatnya jarak dan gangguan antara pemancar dan penerima memengaruhi besar intensitas cahaya yang diterima oleh fotodioda. Apabila antara LED dan fotodioda tidak terhalang oleh benda, maka fotodioda akan aktif.

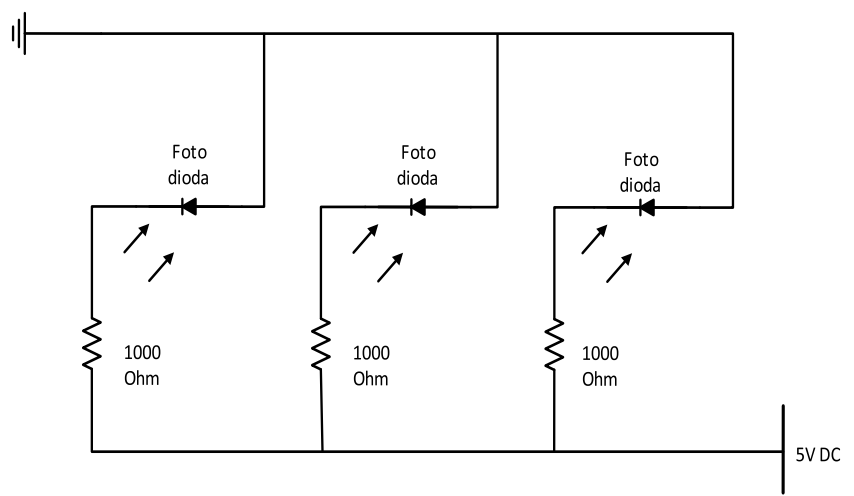

- Gambar 3 Rangkaian Modul Pendeteksi Ketinggian Air

Tabel 4. Hasil Pengujian Modul PPI

\begin{tabular}{cc}
\hline $\begin{array}{c}\text { Pengujian Sensor } \\
\text { ke - }\end{array}$ & $\begin{array}{c}\text { Kondisi Sensor pada Layar } \\
\text { Tampilan Smartphone Android }\end{array}$ \\
\hline 1 & Terdeteksi \\
2 & Terdeteksi \\
3 & Terdeteksi \\
\hline
\end{tabular}

Berdasarkan hasil pengujian, maka dapat disimpulkan bahwa sensor inframerah bekerja dengan baik. Perubahan ketinggian level air pada tampilan smartphone Android berubah ketika sensor mendeteksi adanya halangan atau pergerakan dari pengujian.

\section{Modul Bluetooth}

Bluetooth adalah suatu peralatan media komunikasi yang dapat digunakan untuk menghubungkan sebuah perangkat komunikasi dengan perangkat komunikasi lainnya, Bluetooth umumnya digunakan di handphone, komputer atau PC, tablet, dan lain-lain. Fungsi Bluetooth yaitu untuk mempermudah berbagi atau sharing file, audio, menggantikan penggunaan kabel dan lain-lain. Saat ini sudah banyak sekali perangkat yang menggunakan Bluetooth. Bluetooth beroperasi dalam pita frekuensi 2,4 GHz.

Teknologi Bluetooth ini diciptakan bukan hanya untuk menggantikan atau menghilangkan penggunaan media kabel dalam melakukan pertukaran data atau informasi, tetapi juga mampu menawarkan fitur yang bagus atau baik untuk teknologi wireless atau tanpa kabel, dengan biaya yang relatif rendah, konsumsi daya rendah, mudah dalam pengoperasiannya dan juga mampu menyediakan berbagai macam layanan.

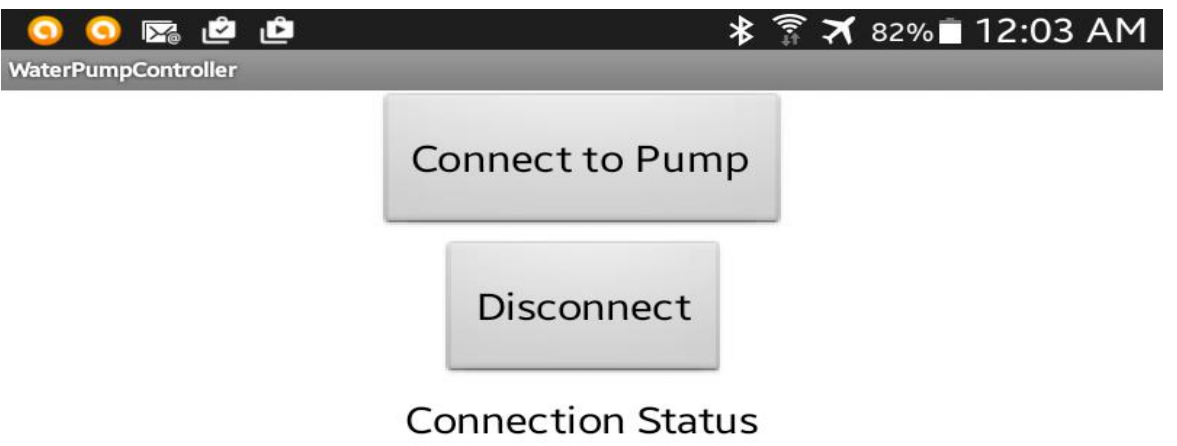

- Gambar 4. Tampilan Konekasi Pompa Air dengan Bluetooth 


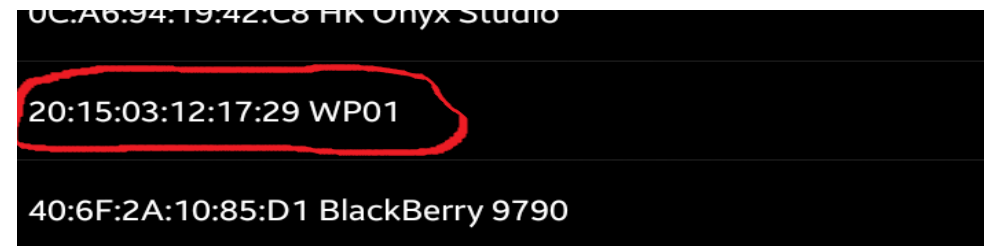

n Gambar 5. Pilihan Devais Bluetooth untuk Pairing

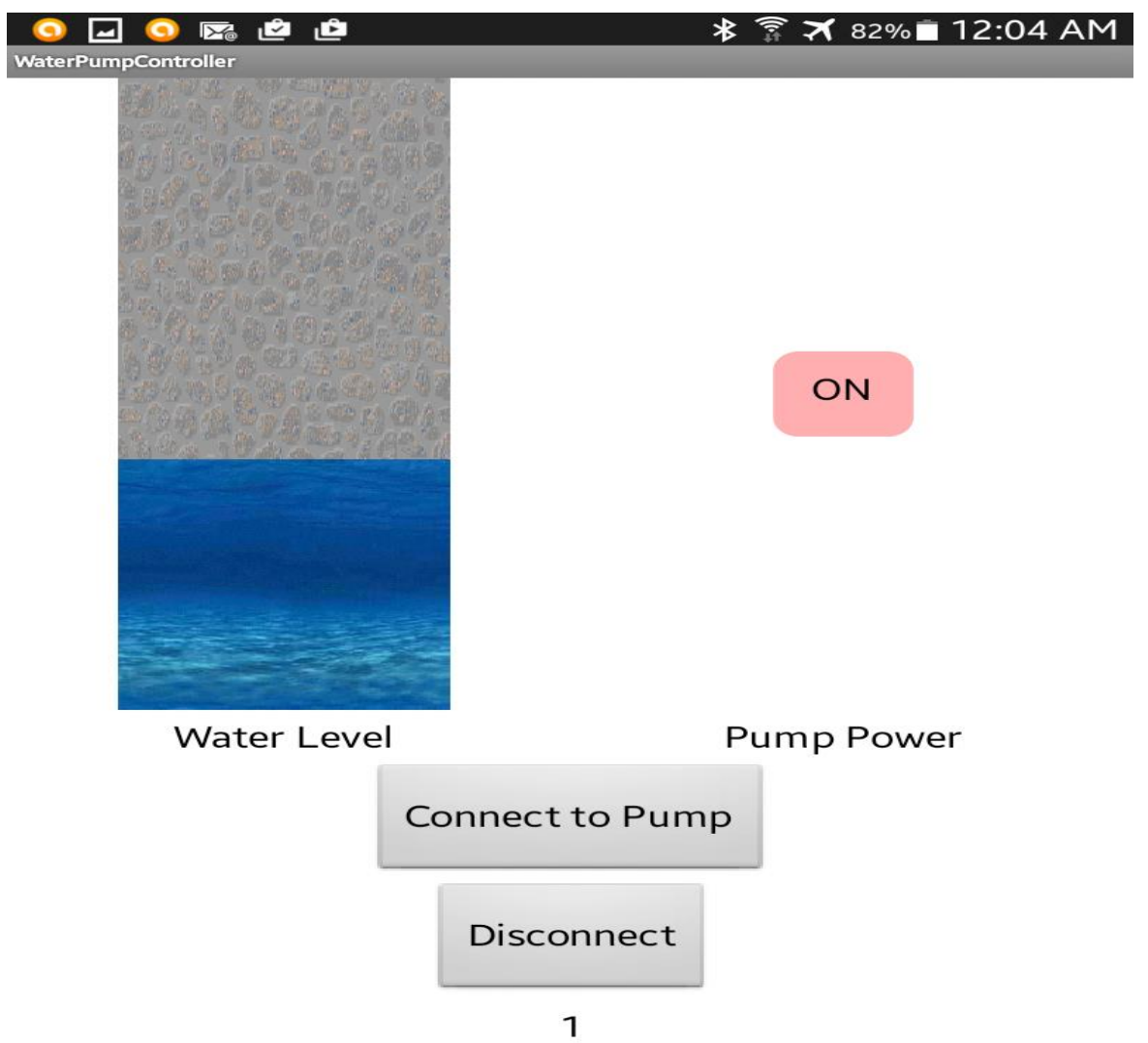

- Gambar 6. Tampilan Pada Saat Pompa Air Aktif

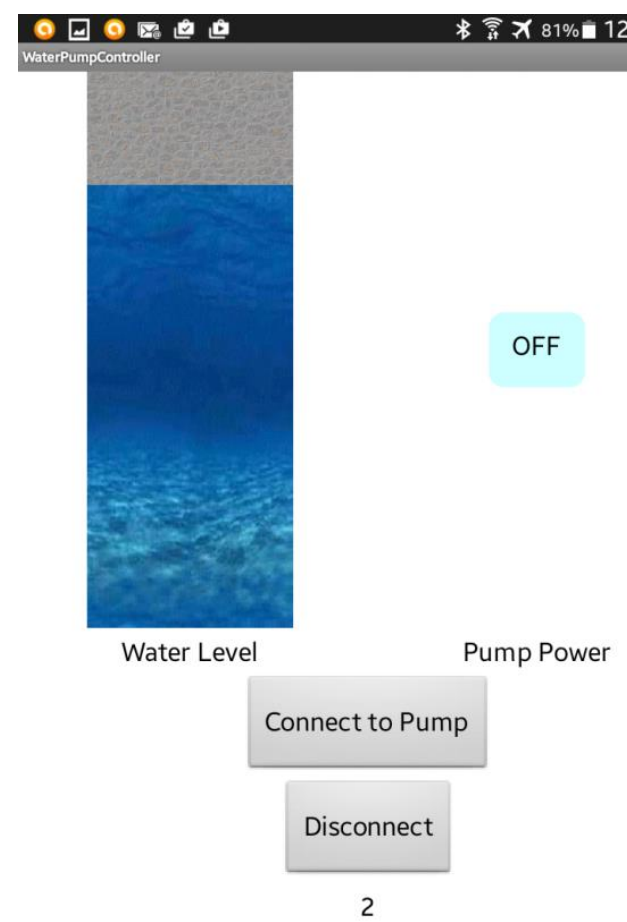


- Gambar 7. Kondisi Air pada Tingkat 2

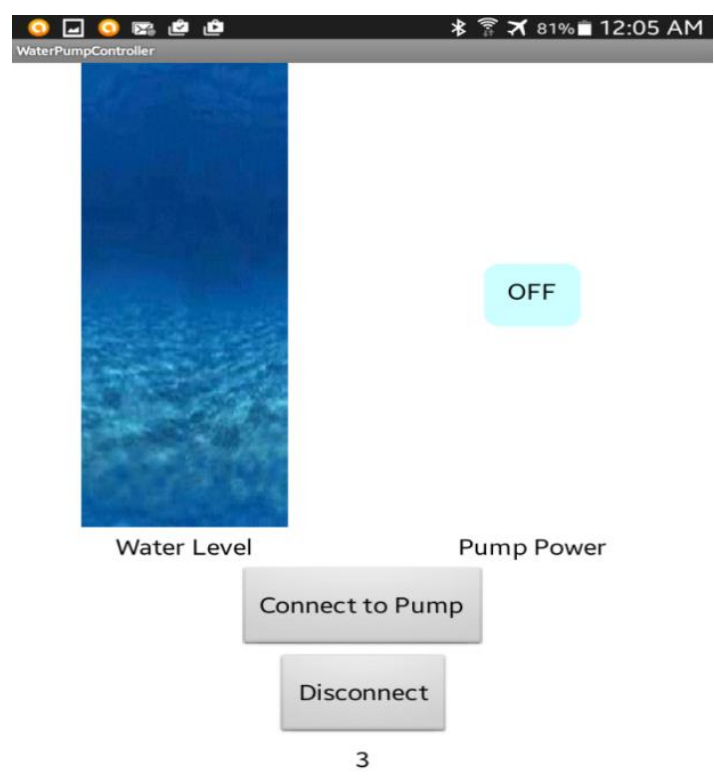

n Gambar 8. Kondisi Air Penuh pada Tingkat 3

Tabel 5. Hasil Pengujian Modul Bluetooth

\begin{tabular}{cc}
\hline $\begin{array}{c}\text { Jarak antara Modul Bluetooth } \\
\text { dengan smartphone Android }\end{array}$ & $\begin{array}{c}\text { Sistem Dapat dikendalikan } \\
\text { (Ya/Tidak) }\end{array}$ \\
\hline 2 Meter & Ya \\
\hline 4 Meter & Ya \\
\hline 6 Meter & Ya \\
\hline 8 Meter & Ya \\
\hline 10 Meter & Ya \\
\hline
\end{tabular}

\section{Modul Mikrokontroler}

Mikrokontroler berasal dari kata microcontroller yang berarti pengendali mikro. Mikrokontroler dapat juga disebut sebagai pengendali mikro karena mikrokontroler secara fisik adalah sebuah keping kecil (microchip) yang merupakan komponen elektronika terintegrasi, dan dalam aplikasinya mikrokontroler berfungsi untuk mengendalikan sebuah pekerjaan tertentu secara terprogram. Mikrokontroler adalah single chip komputer yang memiliki kemampuan untuk diprogram dan digunakan untuk tugas-tugas yang berorientasi kendali (control).

Terdapat beberapa vendor yang membuat mikrokontroler di antaranya Intel, Microchip, Winbond, Atmel, Philips, Xemics dan lain-lain. Dari beberapa vendor tersebut, yang paling populer digunakan adalah mikrokontroler buatan Atmel. Mikrokontroler AVR (Alf and Vegard's Risc prosesor) memiliki arsitektur RISC 8 bit, di mana semua instruksi dikemas dalam kode 16-bit (16-bits word) dan sebagian besar instruksi dieksekusi dalam 1 (satu) siklus clock. Semua mikrokontroler AVR memiliki jenis memori program Flash yang dapat diprogram ulang.

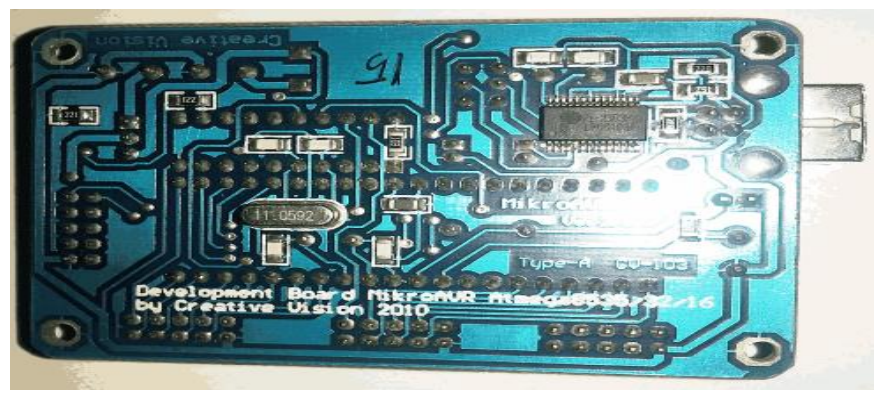




\section{Pompa Air}

Pompa adalah suatu mesin/alat yang digunakan untuk menaikan cairan dari permukaan yang lebih rendah ke permukaan yang lebih tinggi atau memindahkan cairan dari tempat yang bertekanan yang rendah ke tempat yang bertekanan yang lebih tinggi. Pompa bekerja dengan cara mentransfer energi mekanis dari suatu sumber energi luar ke cairan yang mengalir melaluinya. Pompa menaikkan energi cairan yang mengalir melaluinya, sehingga cairan tersebut dapat mengalir dari permukaan yang lebih rendah ke permukaan yang lebih tinggi maupun dari tempat bertekanan rendah ke tempat yang bertekanan lebih tinggi dan bersamaan dengan itu bisa juga mengatasi tahanan hidrolis sepanjang pipa yang dipakai.

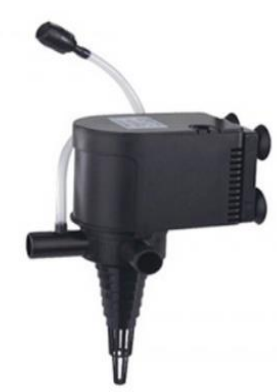

\section{Smartphone}

- Gambar 10. Pompa Air

Smartphone adalah telepon pintar yang memiliki kemampuan seperti komputer. Smartphone diklasifikasikan sebagai high end mobile phone yang dilengkapi dengan kemampuan mobile computing. Dengan kemampuan mobile computing tersebut, smartphone memiliki kemampuan yang tak bisa dibandingkan dengan ponsel biasa. Smartphone yang pertama kali muncul merupakan kombinasi dari fungsi suatu personal digital assistant (PDA) dengan telepon genggam ataupun telepon dengan kamera. Seiring dengan perkembangannya, kini smartphone juga mempunyai fungsi sebagai media player portable, low end digital compact camera, pocket video camera dan GPS. Smartphone modern juga dilengkapi dengan layar touchscreen resolusi tinggi, browser yang mampu menampilkan full web seperti pada PC, serta akses data WiFi dan internet broadband.

Android adalah software untuk perangkat mobile yang meliputi sistem operasi, middleware dan aplikasi inti. Android dilengkapi dengan Android SDK (Software Development Kit) yang menyediakan tools dan mendukung kebutuhan API (Application Programming Interface) yang diperlukan untuk mengembangkan aplikasi pada platform Android dengan menggunakan bahasa pemrograman Java.

\section{HASIL DAN PEMBAHASAN}

Pengujian keseluruhan sistem dilakukan dengan cara menghubungkan semua modul-modul yang digunakan pada perancangan sistem pompa otomatis ini. Pengujian keseluruhan sistem bertujuan untuk memeriksa apakah sistem yang dirancang dapat bekerja dengan baik. Pengujian diawali dengan membuka aplikasi pada smartphone Android yang telah dirancang. Setelah dibuka maka akan muncul tampilan untuk koneksi pada pompa air melalui Bluetooth. Pada tampilan koneksi terdapat tombol untuk koneksi ke pompa air dan tombol untuk memutus hubungan dengan pompa yang berfungsi ketika sedang menghubungkan sistem pompa dengan smartphone Android. Pengujian dilakukan dengan menghubungkan sistem pompa dengan smartphone Android melalui tombol Connect to Pump maka akan muncul pilihan untuk memulai pair pada pilihan devais Bluetooth. Pengisian wadah oleh sistem pompa otomatis ini memiliki tampilan seperti saat mengisi baterai telepon genggam dan naik setingkat setiap melewati modul indikator dan modul pendeteksi ketinggian air. Pada pengujian ini hanya menggunakan model simulasi yang memiliki 3 tingkat level ketinggian air dan memiliki jarak $6 \mathrm{~cm}$ antar tingkat sensor.

\section{KESIMPULAN}

Kesimpulan yang dapat diambil pada perancangan sistem ini adalah Seluruh modul bekerja dan terhubung dengan baik sehingga menghasilkan sistem pompa otomatis sesuai dengan yang diharapkan pada perancangan ini. Monitoring level ketinggian air akan lebih akurat dan presisi pada wadah yang lebih besar jika menggunakan sensor dalam jumlah banyak dan jenis pelampung yang besar dan mampu menghalangi sinyal antar sensor. Sistem pompa otomatis ini memiliki fitur untuk memilih sistem pompa yang akan dikontrol dari smartphone Android, sehingga tidak terbatas hanya pada pengontrolan satu sistem pompa. 


\section{DAFTAR PUSTAKA}

[1] A.A. Putra, Praktis Android A-Z Edisi 1.0. Jakarta, 2012.

[2] H. Wibawanto, Elektronika Dasar : Pengenalan Praktis. Jakarta : Elex Media Komputindo, 2007.

[3] BLUETOOTH: Teknologi Komunikasi untuk Layanan Multimedia dengan Jangkauan Terbatas, tersedia di elektroindonesia.com/elektro/khu36.html (25 April 2015)

[4] R. Boylestad and L. Nashelsky, Electronic Devices and Circuit Theory, 7th ed. New Jersey: Prentice Hall, 1999.

[5] W. Stallings. Wireless Communications \& Networks, Upper Saddle River, New Jersey: Pearson Prentice Hall, 2005

[6] N.G. Ruwano, Berkarya dengan Mikrokontroler AT89C2051, Jakarta: Exel Media Komputindo, 2006.

“ T. L. Floyd, Principles Of Electric Circuits, 4nd Edition, New York: Macmillan Publishing Company, 1993. 